\title{
Simple and Inexpensive Methods Development for Determination of Venlafaxine Hydrochloride from Its Solid Dosage Forms by Visible Spectrophotometry
}

\author{
K. RAGHUBABU ${ }^{* 1}$, L. SHANTI SWARUP ${ }^{1}$, B. KALYANARAMU ${ }^{2}$ M. N. RAO ${ }^{3}$, \\ AND C. RAMDAS ${ }^{3}$ \\ ${ }^{1}$ Department of Engineering Chemistry, AU College of Engineering (A), Andhra University, \\ Visakhapatnam-530003, AP (India) \\ ${ }^{2}$ Department of Chemistry, M. R. College for Men (A), Vizianagaram-535002, AP (India). \\ ${ }^{3} \mathrm{M} / \mathrm{s}$ Tyche Industries, Hyderabad, AP (India).
}

Received 22 November 2011; Accepted 15 January 2012

\begin{abstract}
Two simple, sensitive and cost effective visible spectrophotometric methods (M1 and M2) have been developed for the determination of venlafaxine hydrochloride from bulk and tablet dosage forms. The method M1 is based on the formation of green colored coordination complex by the drug with cobalt thiocyanate which is quantitatively extractable into nitro benzene with an absorption maximum of $626.4 \mathrm{~nm}$. The method M2 involves internal salt formation of aconitic anhydride, dehydration product of citric acid [CIA] with acetic anhydride [Ac2O] to form colored chromogen with an absorption maximum of $561.2 \mathrm{~nm}$. The calibration graph is linear over the concentration range of $10-50 \mu \mathrm{g} / \mathrm{mL}$ and $8-24 \mu \mathrm{g} / \mathrm{mL}$ for method M1 and M2 respectively. The proposed methods are applied to commercial available tablets and the results are statistically compared with those obtained by the reference method and validated by recovery studies. The results are found satisfactory and reproducible. These methods are applied successfully for the estimation of the venlafaxine hydrochloride in the presence of other ingredients that are usually present in dosage forms.
\end{abstract}

Keywords: Anti-depressant, Acetic anhydride, Citric acid, CTC, Colorimetric, Nitrobenzene, Regression analysis.

\section{Introduction}

Venlafaxine hydrochloride (VX) is a bicyclic third generation antidepressant chiral compound of phenethyl amine type with a novel chemical structure ${ }^{1,2}$ (Fig.1). 
<smiles>COc1ccc(C(CN(C)C)C2(O)CCCCC2)cc1</smiles>

Figure 1. Chemical structure of Venlafaxine hydrochloride.

It is chemically designated as (R/S)-1-[2-(dimethyl amino)-1-(4-methoxy phenyl)ethyl] cyclohexanol hydrochloride salt and is usually categorized as a serotonin-nor epinephrine reuptake inhibitor (SNRI) but it has been referred to as a serotonin-norepinephrinedopamine reuptake inhibitor. It weakly inhibits the reuptake of dopamine. VX is well absorbed, with peak plasma concentrations occurring approximately 2 hours after dosing. It is extensively metabolized, to O-desmethyl venlafaxine, the only major active metabolite. It has the empirical formula of $\mathrm{C}_{17} \mathrm{H}_{27} \mathrm{NO}_{2}$. $\mathrm{HCl}$. Its molecular weight is 313.87 . The drug is official in $\mathrm{BP}^{3}$ and suggests potentiometric method for the determination of $\mathrm{VX}$ in bulk and tablet formulations.

Various methods have been reported for the estimation of venlafaxine hydrochloride in biological matrices such as plasma, which include the use of liquid chromatography (LC) with UV detection ${ }^{4}$, LC with electro spray ionization mass spectrometry ${ }^{5}$, LC with coulometric detection $^{6}$, LC with fluorimetric detection ${ }^{7,8}, \mathrm{LC}$ with diode array detection ${ }^{9,10}$, gas chromatography-mass spectrometry $(\mathrm{GC}-\mathrm{MS})^{11}, \mathrm{LC}^{-M S^{12}}{ }^{1}$ LC-MS-MS ${ }^{13,14}$, and for the estimation in serum by using LC $^{15}$, HPLC methods ${ }^{16-22}$, HPLC-MS/ESI ${ }^{23}$, voltammetry $^{24}$,Capillary Electrophoresis ${ }^{25,26}$, Flow injection analysis ${ }^{27}$. Stability indicating methods have also been reported for its in vitro determination in gastric and intestinal fluids ${ }^{28}$ and pharmaceutical formulations ${ }^{29}$, few UV ${ }^{30-33}$ and Visible Spectrophotometry ${ }^{34-}$ 38. However analytical important functional groups in VX have not been exploited properly in developing visible spectrophotometric methods and most of the previous methods involve sophisticated equipments which are costly and pose problems of maintenance.

For routine analysis, simple, rapid and cost effective visible spectrophotometric methods are required and preferred. The main purpose of the present study was to establish relatively simple, sensitive, validated and inexpensive visible spectrophotometric methods for the determination of VX in pure form and in pharmaceutical dosage forms. So the authors have made some attempts in this direction and succeeded in developing two methods based on the reaction between the drug and cobalt thiocyanate ${ }^{39}\left(\mathrm{M}_{1}\right)$ or drug and citric acid-acetic anhydride reagent ${ }^{40}\left(\mathrm{M}_{2}\right)$. These methods can be extended for the routine assay of VX formulations.

\section{Experimental}

A Systronics UV/Visible spectrophotometer model -2203 with $10 \mathrm{~mm}$ matched quartz cells was used for all spectral measurements. A Systronics $\mu$ - $\mathrm{pH}$ meter model-362 was used for $\mathrm{pH}$ measurements. All the chemicals used were of analytical grade. 
CTC $\left(2.50 \times 10^{-1} \mathrm{M}\right.$, solution prepared by dissolving $7.25 \mathrm{~g}$ of cobalt nitrate and $3.8 \mathrm{~g}$ of ammonium thiocyanate in $100 \mathrm{~mL}$ distilled water), Citrate buffer $\mathrm{pH}(2.0)$ (prepared by mixing $306 \mathrm{ml}$ of $0.1 \mathrm{M}$ trisodium citrate with $694 \mathrm{~mL}$ of $0.1 \mathrm{M} \mathrm{HCl}$ and $\mathrm{pH}$ was adjusted to 2.0) were prepared for method $M_{1}$.

Citric acid monohydrate (Prepared by dissolving 1.2 grams of $\left(1.2 \%, 6.245 \times 10^{-2} \mathrm{M}\right)$ Citric acid in $5 \mathrm{~mL}$ methanol initially followed by dilution up to $100 \mathrm{~mL}$ with acetic anhydride) and Acetic anhydride (SD Fine chemicals) were used for Method $\mathrm{M}_{2}$.

\section{Preparation of Standard and Sample Drug Stock Solution}

An accurately weighed quantity of VX (pure or tablet powder) equivalent to $100 \mathrm{mg}$ was mixed with $5 \mathrm{~mL}$ of $10 \% \mathrm{Na}_{2} \mathrm{CO}_{3}$ solution and transferred into $125 \mathrm{ml}$ separating funnel. The freebase released was extracted with $3 \times 15 \mathrm{~mL}$ portion of chloroform and the combined chloroform layer was brought up to $100 \mathrm{~mL}$ with the same solvent to get $1 \mathrm{mg} / \mathrm{mL} \mathrm{VX}$ drug stock solution in free base form. This free base stock solution was further diluted step wise with the same solvent to get the working standard solution concentrations $\left[\mathrm{M}_{1}-500 \mu \mathrm{g} / \mathrm{mL}\right.$, $\left.\mathrm{M}_{2}-200 \mu \mathrm{g} / \mathrm{mL}\right]$.

\section{Procedure /Assay}

\section{Method $M_{1}$}

Aliquots of standard VX solution $(0.5 \mathrm{~mL}-2.5 \mathrm{~mL}, 500 \mu \mathrm{g} / \mathrm{mL}$ in free base form) were delivered into a series of $125 \mathrm{~mL}$ separating funnels. Then $2.0 \mathrm{~mL}$ of buffer solution $(\mathrm{pH} 2.0)$ and $5.0 \mathrm{~mL}$ CTC solution were added. The total volume of aqueous phase in each separating funnel was adjusted to $15.0 \mathrm{~mL}$ with distilled water. To each separating funnel $10.0 \mathrm{~mL}$ of nitrobenzene was added and contents were shaken for 2 minutes. The two phases were allowed to separate and absorbance of nitrobenzene layer was measured at $626.4 \mathrm{~nm}$ against a similar reagent blank (Fig-2 showing absorption spectra). The colored product was stable for 1 hour. The amount of VX in the sample solution was computed from its calibration graph (Fig-3 showing Beer's law plot).

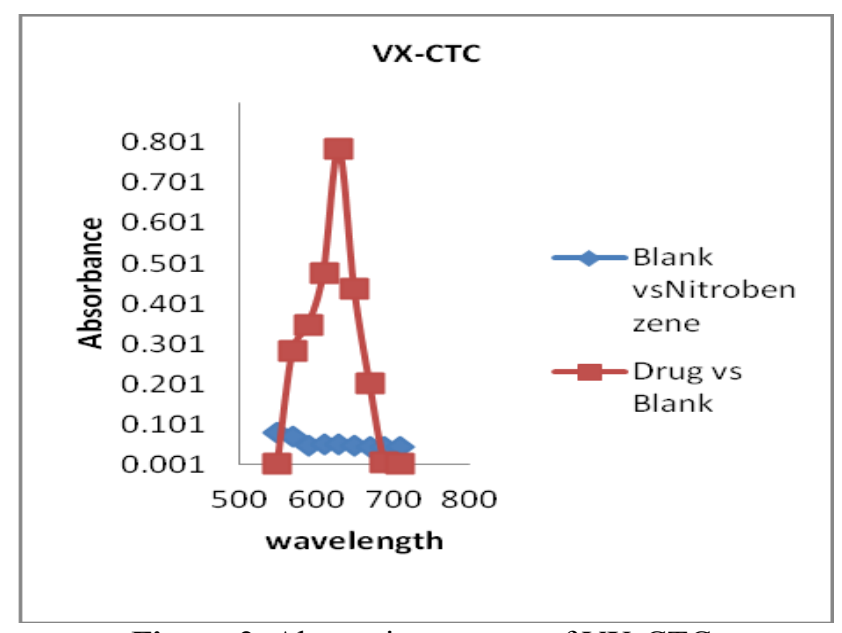

Figure 2. Absorption spectra of VX-CTC. 


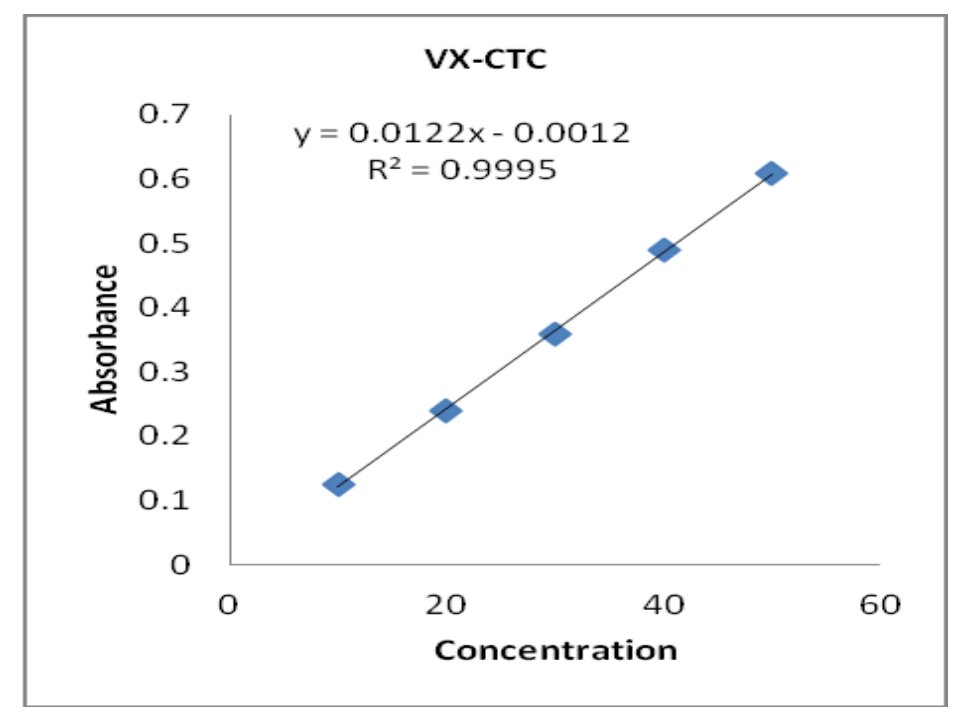

Figure 3. Beer's Law plot of VX-CTC.

\section{Method $M_{2}$}

Aliquots of standard VX drug solution $[1.0-3.0 \mathrm{~mL} ; 200 \mu \mathrm{g} / \mathrm{mL}$ in free base form] in chloroform were taken into a series of $25 \mathrm{~mL}$ graduated tubes and gently evaporated in a boiling water bath to dryness. To this, $10 \mathrm{~mL}$ of citric acid- Acetic anhydride reagent was added and the tubes were immersed in a boiling water bath for 30 minutes then the tubes were cooled to room temperature and made up to the mark with acetic anhydride. The absorbance of the colored solutions was measured after 15 minutes at $561.2 \mathrm{~nm}$ against the reagent blank (Fig-4 showing absorption spectra) within the stability period of 15 $60 \mathrm{~min}$. The amount of VX was computed from its calibration graph (Fig-5 showing Beer's law plot).

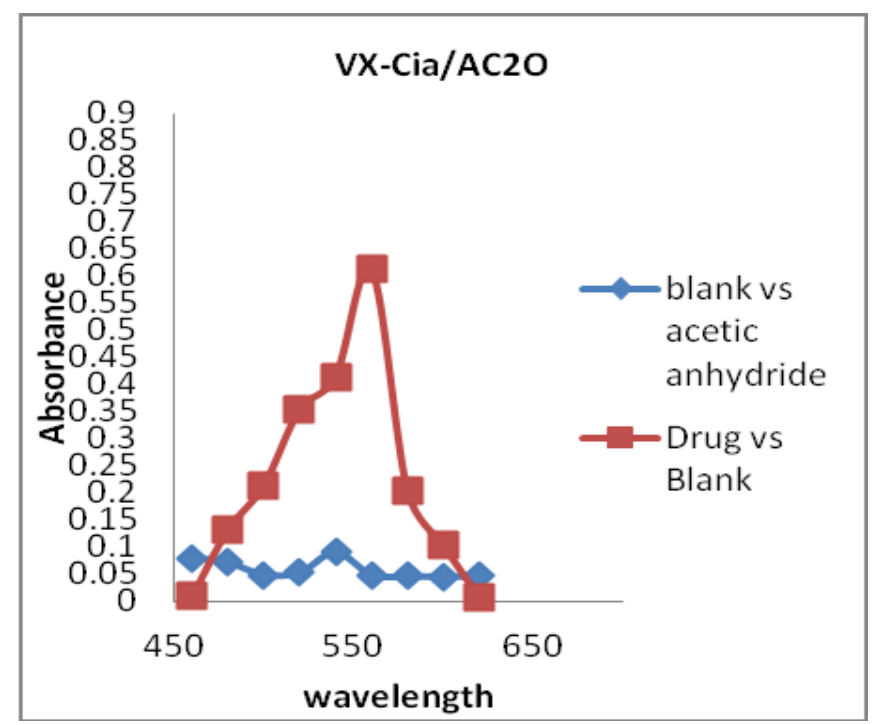

Figure 4. Absorption spectra of $\mathrm{VX}-\mathrm{CA} / \mathrm{AC}_{2} \mathrm{O}$. 


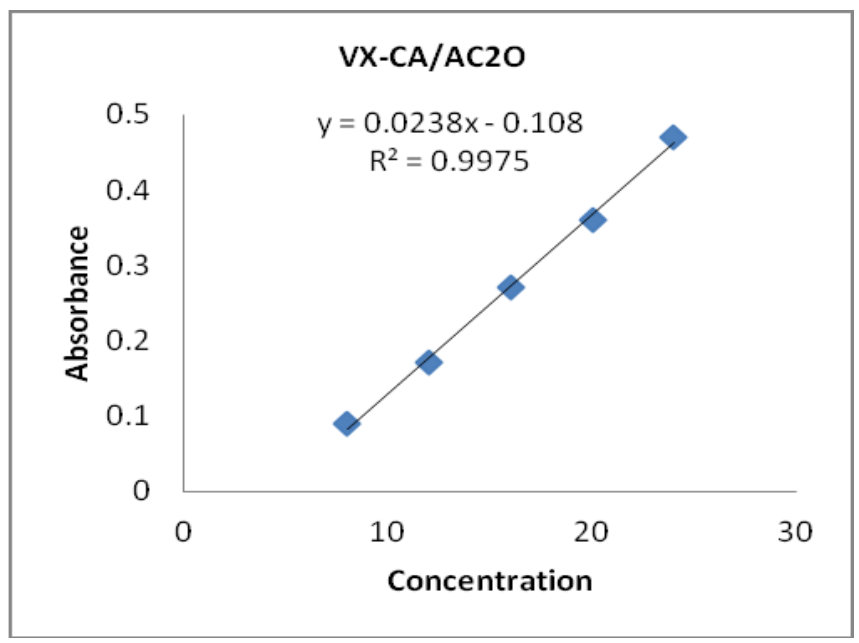

Figure 5. Beer's Law plot of $\mathrm{VX}-\mathrm{CA} / \mathrm{AC}_{2} \mathrm{O}$.

\section{Results and Discussion}

In developing these methods, systematic studies of the effects of various parameters were undertaken by varying one parameter at a time and controlling all others fixed (OVAT method). The effect of various parameters such as time, volume and strength of reagents, $\mathrm{pH}$ buffer solution and order of addition of reagents, stability period and solvent for final dilution of the colored species were studied and the optimum conditions were established. Among the various water immiscible organic solvents $\left(\mathrm{C}_{6} \mathrm{H}_{6}, \mathrm{CHCl}_{3}\right.$, dichloro methane, nitro benzene, chloro benzene and $\mathrm{CCl}_{4}$ ) tested for the extraction of colored coordinate complex into organic layer, nitrobenzene was preferred for selective extraction of colored complex from organic phase in method $\mathrm{M}_{1}$. Different solvents like acetic anhydride, acetic acid, methanol, ethanol, and isopropanol were also used as diluents but acetic anhydride was found to be ideal for final dilution in method $\mathrm{M}_{2}$. The ratio of organic to aqueous phase was found to be $1: 1.5$ by slope ratio method for method $\mathrm{M}_{1}$. The optical characteristics such as Beer's law limit, Sandell's sensitivity, molar absorptivity, percent relative standard deviation, (calculated from the six measurements containing $3 / 4^{\text {th }}$ of the amount of the upper Beer's law limits ) were calculated and the results are summarized in Table-1.

Recovery experiments indicated the absence of interference from the commonly encountered pharmaceutical excipients present in formulations. The proposed methods are found to be simple, sensitive and accurate and can be used for the routine quality control analysis of VX in bulk and dosage forms.

Recovery experiments indicated the absence of interference from the commonly encountered pharmaceutical excipients present in formulations. The proposed methods are found to be simple, sensitive and accurate and can be used for the routine quality control analysis of VX in bulk and dosage forms.

\section{Chemistry of Colored Species}

In method $\mathrm{M}_{1}$ the green color species formed is the coordination complex of the drug (electron donor) and the central metal of cobalt thiocyanate, which is extractable into nitro benzene from aqueous solution and in method $\mathrm{M}_{2}$ red-violet color internal salt of aconitic anhydride is formed when $\mathrm{VX}$ was treated with CTC or CIA/ $\mathrm{Ac}_{2} \mathrm{O}$ reagents. The formations 
of colored species are due to the presence of the tertiary amino group in it. It is based on the analogy of tertiary amine as given in scheme (Fig-6).

Table 1. Optical characteristics, precision and accuracy of proposed methods.

\begin{tabular}{|c|c|c|}
\hline Parameter & Method $M_{1}$ & Method $\mathbf{M}_{2}$ \\
\hline$\lambda_{\max }(\mathrm{nm})$ & 626.4 & 561.2 \\
\hline Beer's law limit $(\mu \mathrm{g} / \mathrm{mL})$ & $10-50$ & $8-24$ \\
\hline $\begin{array}{c}\text { Sandell's sensitivity } \\
\left(\mu \mathrm{g} / \mathrm{cm}^{2} / 0.001 \text { abs. unit }\right)\end{array}$ & 0.003342618 & 0.00237037 \\
\hline $\begin{array}{l}\text { Molar absorptivity } \\
\text { (Liter/mole/cm) }\end{array}$ & 93899.44167 & 132413.9063 \\
\hline $\begin{array}{l}\text { Correlation coefficient } \\
\text { Regression equation } \\
(\mathrm{Y})^{*}\end{array}$ & 0.999 & 0.997 \\
\hline Intercept (a) & -0.001 & -0.108 \\
\hline Slope(b) & 0.012 & 0.023 \\
\hline$\%$ RSD & 0.9948 & 1.3752 \\
\hline $\begin{array}{l}\% \text { Range of errors }(95 \% \\
\text { Confidence limits }) \\
0.05 \text { significance level } \\
0.01 \text { significance level }\end{array}$ & $\begin{array}{l}1.044 \\
1.637\end{array}$ & $\begin{array}{l}1.443 \\
2.26\end{array}$ \\
\hline
\end{tabular}




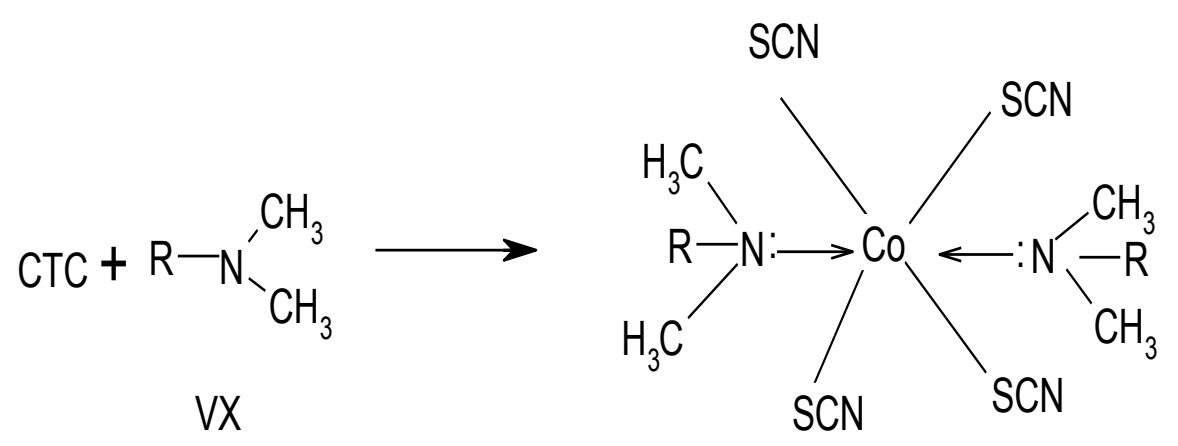

Colored species
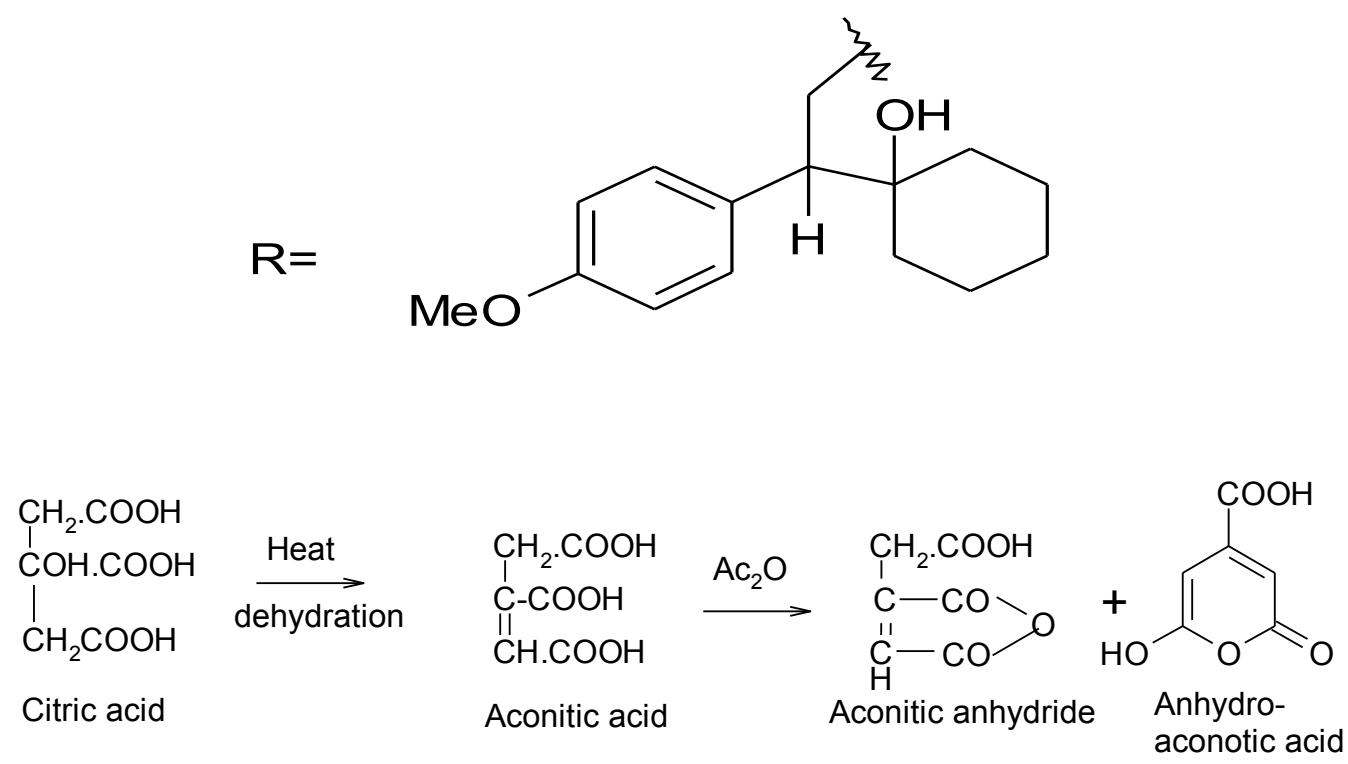

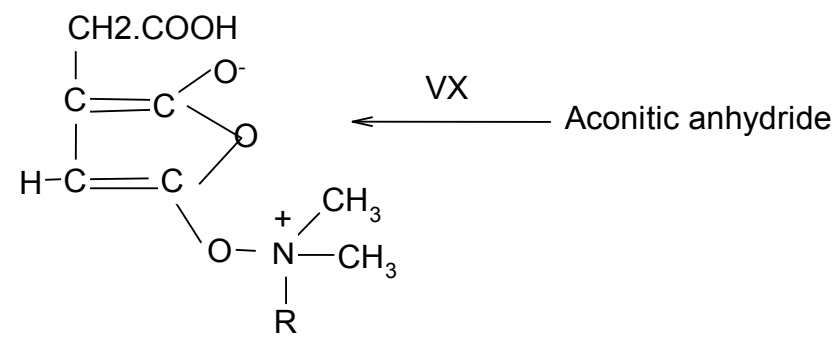

Colored species

Figure 6. Probable Scheme for method $\mathrm{M}_{1} \& \mathrm{M}_{2}$. 
Table 2. Analysis of venlafaxine hydrochloride in pharmaceutical formulations by proposed and reference methods.

\begin{tabular}{|c|c|c|c|c|c|c|c|}
\hline \multirow[t]{2}{*}{$\begin{array}{l}\text { Metho } \\
\text { d }\end{array}$} & \multirow[t]{2}{*}{$\begin{array}{c}\text { *Formulation } \\
\mathrm{s}\end{array}$} & \multirow{2}{*}{$\begin{array}{l}\text { Labeled } \\
\text { Amoun } \\
\mathrm{t}(\mathrm{mg})\end{array}$} & \multicolumn{3}{|c|}{$\begin{array}{c}\text { Found by Proposed } \\
\text { Methods }\end{array}$} & \multirow{2}{*}{$\begin{array}{l}\text { Found by } \\
\text { Reference } \\
\text { Method } \pm \\
\text { SD }\end{array}$} & \multirow{2}{*}{$\begin{array}{c}\# \% \\
\text { Recover } \\
\text { y by } \\
\text { Proposed } \\
\text { Method } \\
\pm \mathrm{SD}\end{array}$} \\
\hline & & & $\begin{array}{l}* * \text { Amoun } \\
\mathrm{t} \text { found } \pm \\
\mathrm{SD}\end{array}$ & $\mathrm{t}$ & $\mathrm{F}$ & & \\
\hline \multirow[t]{2}{*}{$\mathrm{A}$} & Batch-1 & 37.5 & $\begin{array}{c}36.30 \pm \\
0.580\end{array}$ & 0.213 & $\begin{array}{c}4.30 \\
3\end{array}$ & $\begin{array}{c}96.34 \pm 2.3 \\
1\end{array}$ & $\begin{array}{c}96.81 \pm \\
1.55\end{array}$ \\
\hline & Batch-2 & 75 & $\begin{array}{c}72.03 \pm \\
0.553\end{array}$ & 0.768 & $\begin{array}{c}1.49 \\
9\end{array}$ & $\begin{array}{c}95.80 \pm 0.6 \\
0\end{array}$ & $\begin{array}{c}96.05 \pm \\
0.738\end{array}$ \\
\hline \multirow[t]{2}{*}{ B } & Batch-1 & 37.5 & $\begin{array}{c}36.31 \pm \\
0.416\end{array}$ & $\begin{array}{c}0.248 \\
7\end{array}$ & 4.34 & $\begin{array}{c}96.34 \pm 2.3 \\
1\end{array}$ & $\begin{array}{c}96.81 \\
1.11\end{array}$ \\
\hline & Batch-2 & 75 & $\begin{array}{l}72.29 \pm \\
0.842\end{array}$ & 1.92 & 3.48 & $\begin{array}{c}95.80 \pm 0.6 \\
0\end{array}$ & $\begin{array}{l}96.38 \pm \\
1.12\end{array}$ \\
\hline \multicolumn{8}{|c|}{$\begin{array}{l}\text { * Batch 1\&2 from two different companies (Batch-1: Venlor-XR capsules of Cipla (India), } \\
\text { Batch 2: Ventab XL tablets of Intas pharmaceuticals (India). } \\
\text { **Average } \pm \text { Standard deviation of six determinations, the } t \text { - and f-values refer to } \\
\text { comparison of the proposed method with reference method (UV). Theoretical values at } 95 \% \\
\text { confidence limits } t=2.57 \text { and } f=5.05 \text {. \# Recovery of } 10 \mathrm{mg} \text { added to the pre-analyzed } \\
\text { sample (average of three determinations). Reference method (reported UV method) using } \\
\text { double distilled water }\left(\lambda_{\max }=224 \mathrm{~nm}\right) \text {. }\end{array}$} \\
\hline
\end{tabular}

\section{Conclusion}

The reagents utilized in the proposed methods are cheap, readily available and the procedures do not involve any critical reaction conditions or tedious sample preparation. The proposed visible spectrophotometric methods are validated as per ICH guide lines and possess reasonable precision, accuracy, simple, sensitive and can be used as alternative methods to the reported ones for the routine determination of VX depending on the need and situation.

\section{Acknowledgment}

The authors are very much thankful to the $\mathrm{m} / \mathrm{s}$ Tychy Industries for providing gift sample of the drug and also thanks to University authorities for providing necessary facilities in this work. 


\section{References}

1. Reynolds JE.F, Eds., In; Martindale, the Extra pharmacopoeia, $31^{\text {st }}$ ed., The Pharmaceutical society, London, 1996, 337.

2. Budavari S, Eds; The Merck Index, 12 th ed. Merck \& Co White house Station, NJ, 1996, 1695.

3. British Pharmacopoeia, 2007, volume II, 6317.

4. Raut BB, Kolte BL, Deo AA, Bagool MA, Shinde DB, J Liq. Chromatogr Technol., 2003, 26, 1297-1313.

5. Juan H, Zhiling Z, Huande L, J Chromatogr B Analyt Technol Biomed Life Sci., 2005, 820, 33-39.

6. Clement EM, Odontiadis J, Franklin M, J Chromatogr B Biomed Sci. Appl., 1998, 705, 303-308.

7. Vu RL, Helmeste D, Albers L, Reist C, J Chromatogr B Biomed Sci Appl., 1997,703, 195-201

8. Li HD, Diang DR, Zhang BK, Yuan HY, Yaowu Fenxi Zazhi, 2001, 21, 240-242.

9. Duverneuil C, de la Grandmaison GL, de Mazancourt P, Alvarez JC, Ther Drug Monit, 2003, 25, 567-73.

10. Titier K, Castaing N, Scotto-Gomez E, Molimard M, Ther Drug Monit, 2003, 25, 581 587.

11. Wille SM, Maudens KE, Van Peteghem CH, Lambert WE, J Chromatogr A. 2005, 1098, 19-29.

12. Wei z, Bing-Ren X, Cai.Yun W, Biomed Chromatography, 2007, 21(3), 266-272.

13. Shah GR, Thaker BT, Surathi KR and Parabia MH, Analytical Sciences, 2009, 25, 1207-1210.

14. Bhatt J, Jangid A, Venkatesh G, Subbaiah G, Singh S, J Chromatogr B Analyt Technol Biomed Life Sci., 2005, 829, 75-81.

15. Frahnert C, Rao ML, Grasmäder K, J Chromatogr B Analyt Technol Biomed Life Sci., 2003, 794, 35-47.

16. Baldania SL, Bhatt KK, Mehta RS, Shah DA and Tejal R. Gandhi, Indian Journal of Pharmaceutical Sciences, 2008, 70(1), 124-128.

17. Vidyavathi M, Krishna DR, Prasad KVSRG and Vidyasagar J, Current Trends in Biotechnology and Pharmacy, 2009, 3(1), 64-70.

18. Wachgler R, Moll W, Konig P and Conca A, Int. J. Clin Pharmacol Ther., 2004, 42, 724-728.

19. Tournel G, Handret N, Hedouin VD, Eveaux M, Gosset D and Lhermitte M, J. Chromatography B, 2001,761, 147-158.

20. Matoga M, Derhourca F, Titier K, Dumore F and Jarry C, J. Chromatography B Biomed Sci., 2001, 760, 213-218.

21. Maryam Hosseini, Turk J. Pharm. Sci., 2011, 8(2), 91-104.

22. Yang X, Jim M, Zhou J, Xiao Li S, Wen AD, J. Chromatogr. B, 2008, 872, 38-42.

23. Juan H, Zhiling Z, Huande L, J Chromatogra Bio Sci., Appl. 2005, 820, 33-39.

24. LF-Limba, Jose Debbie V Loo, Cristina Delerue-Matos, Aida S Roque da Sila, II Farmco, 1999, 54(3), 145-148.

25. Nicoleta Carmen Purdel, Danbalalau Mihaela Ilie, Corina Cristina Arama, Farmacia, 2010, 58(1), 62-69.

26. Cherkaoui S, Rudaz S, Venthey J, Journal of Electrophoresis, 2001, 22, 491-496.

27. Paraskevas D, Verdoukas A, Demetrius G, Analytical Sciences, 2005, 21, 1515.

28. Asafu-Adjaye EB, Faustino PJ, Tawakkul MA, Anderson LW, Yu LX Kwon H, et al. $J$ Pharm Biomed Anal., 2007, 43, 1854-1859.

29. Makhija SN, Vavia PR, J Pharm Biomed Anal., 2002, 28, 1055-1059. 
30. Patel B, Patel J, Banwait H, Darji N, Patel D, Patel AGB, Patel M, Journal of Institutional Pharmacy and Life Sciences, 2011, 1(1), 153-163.

31. Sundaraganapathy R, Jambulingam M, Ananda Thangadurai, Subasini U, Int. J. Pharm \& Ind. Res., 2011, 1(1), 28-31.

32. Basaveswara Rao MV, Reddy BCK, Srinivasa Rao T, Prasanthi V, RASAYAN J. Chem., 2009, 2(2), 276-279.

33. Vimal D Shirvi, Vijaya kumar G, Channabasavaraj KP, International Journal of Pharm Tech Research, 2010, 2(1), 700-703.

34. Pillai S, Singhavi I, the Indian Pharmacist, 2006, 5, 75-76.

35. Onal A, Kepekci SE, Cetin SM, Erturk S, Journal of AOAC International, 2006, 89(4), 966-971.

36. Rajasekaran A, Arulkumaran M, Kannanraj S, Indian Journal of Pharmaceutical Sciences, 2004, 66(1), 101-103.

37. Padmanabha Reddy, Y and Prabhakar G, International Journal of Chemical Sciences, 2006, 4(1), 151-156.

38. Sowmya C, Reddy YP, Kirankumar M and Santhosh Raja M, International Journal of Chemical Sciences, 2011, 9(1), 52.

39. Zarapker SS, Rele RV, and Doshi VJ, Indian drugs, 1987, 24 (12), 560-564.

40. Massart DL, Vandegingtc BGM, Perming SM, Michotte Yand Kaufman L, Chemo metrics, A text book, Elsevier, Amsterdam, 1988, 283. 


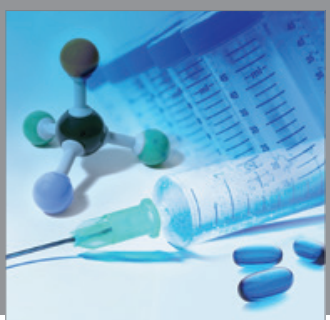

International Journal of

Medicinal Chemistry

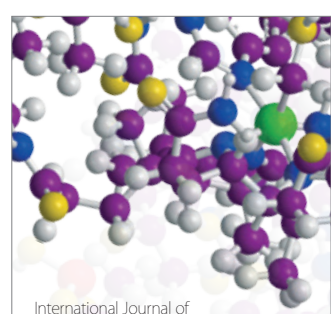

Carbohydrate Chemistry

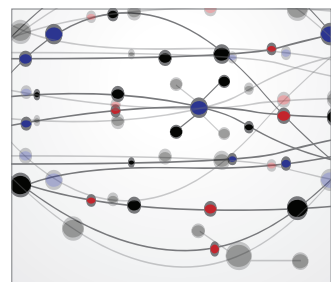

The Scientific World Journal
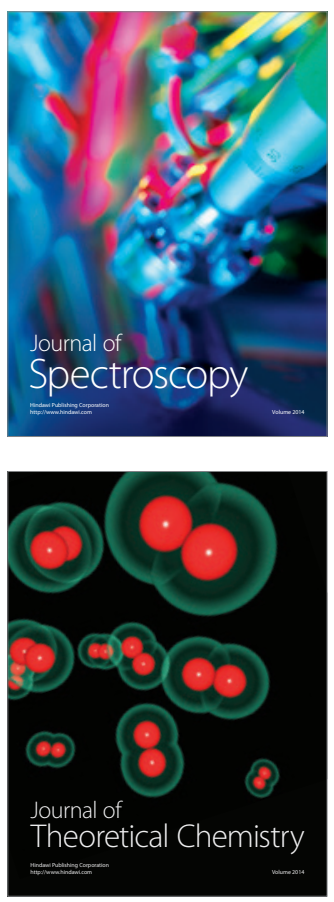
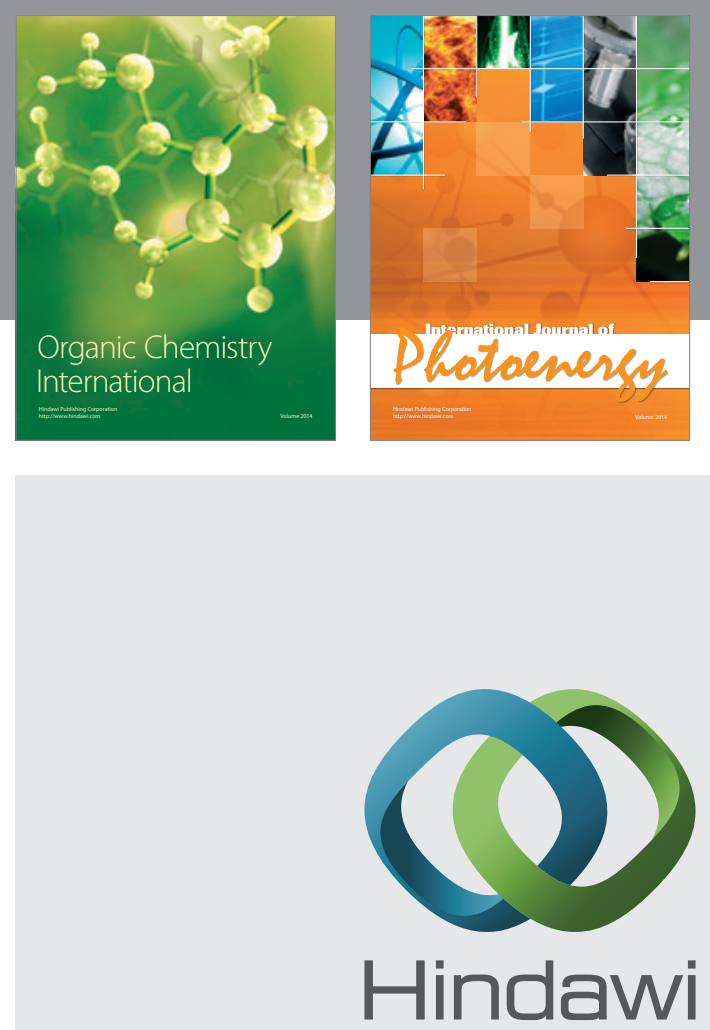

Submit your manuscripts at

http://www.hindawi.com
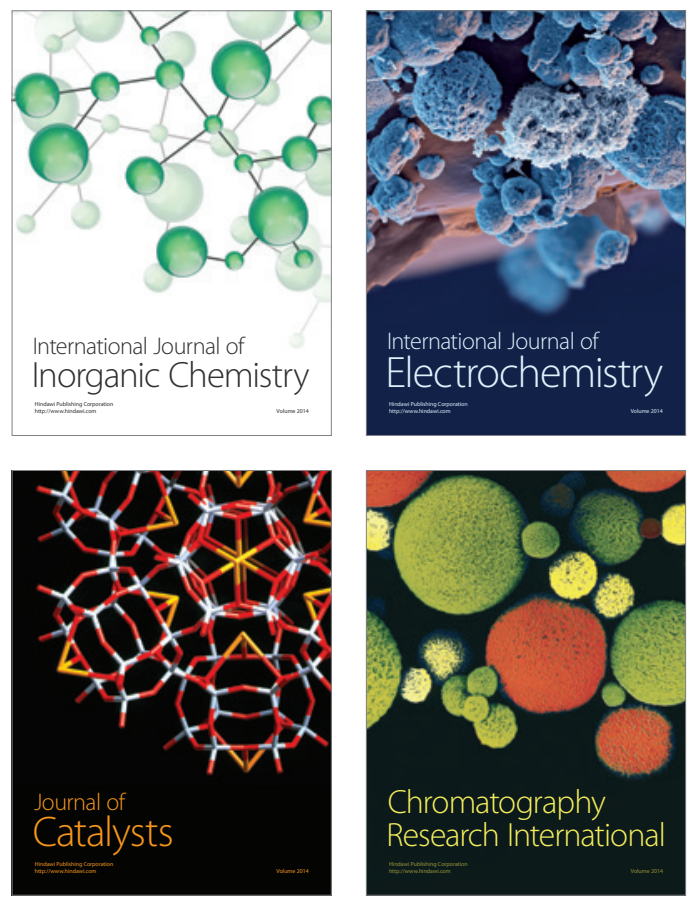
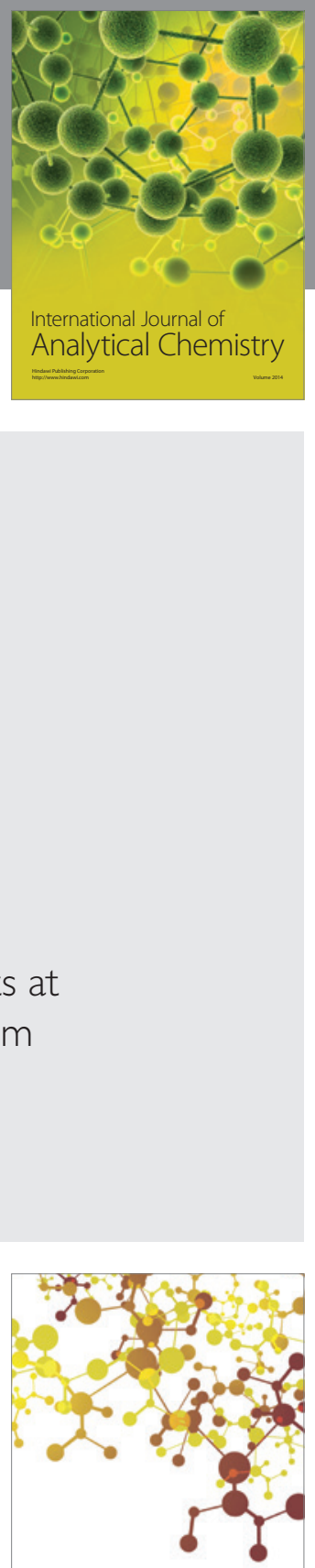

Journal of

Applied Chemistry
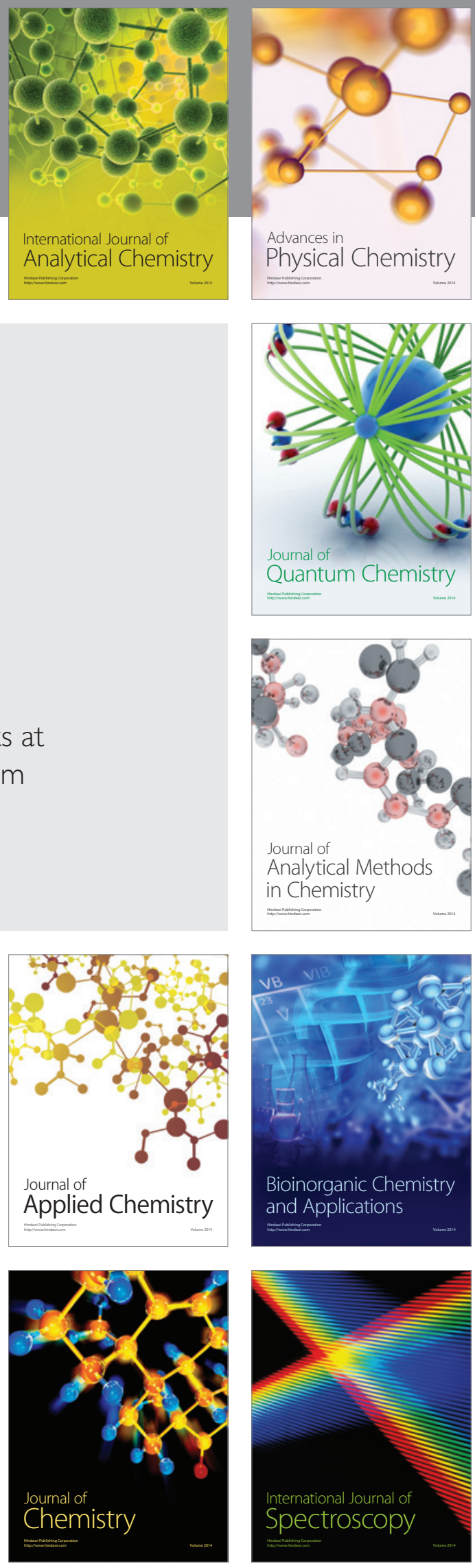